\title{
Ekmeklik Buğday Genotiplerinin Verim ve Fenolojik Özelliklerinin Tane Doldurma Dönemindeki Kuraklık Stresine Tepkileri
}

\author{
*Ramazan AYRANCI', Bayram SADE², Süleyman SOYLU² \\ ${ }^{1}$ Ahi Evran Üniversitesi, Ziraat Fakültesi, Tarla Bitkileri Bölümü, Kırșehir \\ ${ }^{2}$ Selçuk Üniversitesi, Ziraat Fakültesi, Tarla Bitkileri Bölümü, Konya \\ *Sorumlu yazar e-posta (Corresponding author e-mail): ramazanayranci@ahievran.edu.tr
}

\begin{abstract}
Öz
Bu çalıșmanın amacı Orta Anadolu Bölgesi'nde tane doldurma döneminde görülebilen kuraklık tipinin modellendiği kontrollü tarla șartlarında, ekmeklik buğday genotiplerinin verim ve bazı fenolojik özelliklerinin tepkilerinin belirlenmesidir. Çalıșma, Konya'da 2009-2010 yetiștirme yıllarında yağmur korunakları altında, tesadüf bloklarında bölünmüș parseller deneme deseninde, dört tekerrürlü; ana parsellerde uygulamalar $\left(S_{1}\right.$ : Tane doldurma dönemi kuraklığı, $S_{2}$ : Tam sulu koșullar) ve alt parsellerde 10 ekmeklik buğday genotipi kullanılarak yürütülmüștür. Çalıșmada, genotiplerin verim ve fenolojik özelliklerinin tane doldurma dönemindeki kuraklı̆̆a tepkileri değerlendirilmiștir. Çalıșmada tane verimi, uygulama ortalamaları olarak $579 \mathrm{~kg} \mathrm{da}^{-1}\left(\mathrm{~S}_{1}\right)$ ile $760 \mathrm{~kg} \mathrm{da}^{-1}\left(\mathrm{~S}_{2}\right)$ arasında ve stres uygulamaları üzerinden genotiplerde $595 \mathrm{~kg} \mathrm{da}^{-1}$ (Göksu 99) ile 725 $\mathrm{kg} \mathrm{da}^{-1}$ (BDME 09/1K) arasında değișmiștir. Stres uygulaması, sulu uygulama ile karșılaștıııldığında, tane dolum dönemi kuraklık uygulamasında tane verimi \%23.9 oranında azalmıștır. KHi değerleri 0.58 (Bayraktar 2000) ile 1.73 (Göksu 99) arasında değișmiștir. Bayraktar 2000 çeșidi tane dolum kuraklı̆ı̆na en toleranslı çeșit olarak belirlenmiștir. Fenolojik özelliklerin uygulama ortalamaları olarak, bașaklanma süresi 168.6 gün ile 171.9 gün, çiçeklenme süresi 174.2 gün ile 178.1 gün, fizyolojik olum süresi 208.9 gün ile 218.1 gün ve tane dolum süresi 34.7 gün ile 39.9 gün arasında değișim göstermiștir. Stres uygulaması sulu koșullara göre, bașaklanma süresinde \%1.9; çiçeklenme süresinde $\% 2.2$; fizyolojik olum süresinde $\% 4.2$; tane dolum süresinde \%13 kısalmaya sebep olmuștur. Tane dolum süresi uzun olan çeșitlerin verim değerlerinin yüksek olduğu belirlenmiștir. Bu çalıșmada tane doldurma dönemi kurak stresi altında ekmeklik buğday genotiplerinde kuraklığa adaptasyonu desteklediği belirlenen tane doldurma süresi parametresi, geç dönemde etkili olan kuraklık için, toleranslı genotip geliștirmek amacıyla, seleksiyon parametresi olarak kullanılabilir.
\end{abstract}

Anahtar Kelimeler: Kuraklık, buğday, fenolojik özellikler, seleksiyon, parametre

\section{The Response on the Drought Stress Yield and Phenological Properties of Bread Wheat Genotypes in Grain Filling Stage}

\section{Abstract}

The aim of this study was to determine the responses of the grain yield and some phenological properties of bread wheat genotypes under controlled field conditions which can be seen in grain filling stage in Central Anatolia Region. This research was conducted to observe the drought resistance of ten bread wheat genotypes at grain filling period. Split-plot in randomized complete block design techniques were used with four replicates in 2009-2010 under rain shelter in Konya Province. Two different irrigation treatments were done in grain filling period drought (S1) and in full irrigation conditions (S2). Results showed that grain yield values varied from $579\left(\mathrm{~S}_{1}\right)$ to $760 \mathrm{~kg} \mathrm{da}^{-1}\left(\mathrm{~S}_{2}\right)$ under drought treatments, and from 595 (Göksu 99) to 725 $\mathrm{kg} \mathrm{da}^{-1}$ (BDME 09/1K). If the means of drought treatment was compared with irrigated treatment, the grain yields of genotypes under grain filling stages drought treatment were $23.9 \%$ reduced. DSI values which were calculated for the grain yield of genotypes ranged between 0.58 (Bayraktar 2000) and 1.73 (Göksu 99). Bayraktar 2000 was determined as a variety which is the most tolerant to grain filling stage drought type. As the treatment average of phenological properties, heading duration was ranged from 168.6 to 171.9 days, flowering duration from 174.2 to 178.1 days, physiological maturity duration from 208.9 to 218.0 days and grain filling duration from 34.7 to 39.9 days. The stress treatment compared to full watered conditions presented shortening: $1.9 \%$ in heading duration, $2.2 \%$ in flowering duration, $4.2 \%$ in physiological maturity duration, and $13 \%$ in grain filling duration. It was determined that cultivars which had longer grain filling durations result in higher grain yields. In this study, it was determined that the grain filling duration parameter which supported the adaptation to drought in bread wheat genotypes under grain filling stage drought stress can be used as a selection parameter to improve the drought tolerant genotypes.

Keywords: Drought, wheat, phenological properties, selection, parameter 


\section{Giriș}

uraklık, dünyada ve ülkemizde yağıșa bağımlı tarım alanlarının büyük bir bölümünde bitkisel üretimi sınırlayan en önemli faktörlerden birisidir. Türkiye'de yetiștirilen buğdayın büyük bir kısmı (\%80) yağıșa bağımlı tarım yapılan alanlarda yetiștirilmektedir; bunun büyük bir bölümünü ise Orta Anadolu ve Geçit Bölgeleri olușturmaktadır. Bu bölgede verimi etkileyen unsurların bașında, yetersiz yağıș miktarı ve yağıșın yetișme periyodu içindeki düzensiz dağılımı gelmektedir (Sade, 2008). Bu durum, kuraklığın șiddetine ve dağılımına bağlı olarak \%40-65'lere varan verim kayıplarına neden olabilmektedir (Öztürk, 1999a).

Düzensiz yağıș dağılımlarının etkisine ek olarak, kuraklık etkisinin bitkiler üzerindeki șiddeti, buğdayın gelișim evresine bağlı olarak da değișkenlik göstermektedir (Gupta et al., 2001). Buğdayda tane veriminin bașlıca kaynağı, bașaklanmadan sonraki kuru madde birikimi olduğu için (Schnyder, 1993; Saidi et al., 2008) bitki gelișme dönemleri bakımından tane dolum dönemi kuraklığı kritik bir öneme sahiptir. Terminal kuraklığın buğdayda verimi ve bu döneme ait fenolojik süreçleri nasıl ve ne ölçüde etkilediğinin iyi anlașılması, bu kuraklık tipine adapte olabilecek genotiplerin ıslahında yardımcı olabilecektir. Bu yüzden, genotiplerin farklı gelișme dönemlerine karșı reaksiyonlarını (Jamal et al., 1996; Czeuz et al., 2008; Saidi et al., 2008), tolerans derecelerini (Fischer and Maurer, 1978) ve bu alanda genetik varyasyonu (Jalal et al., 2014) belirlemek önemli Islah stratejileri olarak kullanılmaktadır.

Bu araștırmada, Orta Anadolu Bölgesi'nde farklı bitki gelișme dönemlerinde görülebilen kuraklık tiplerinin modellendiği kontrollü tarla șartlarında, ekmeklik buğday genotiplerinin verim ve bazı fenolojik özelliklerin tane dolum dönemi kuraklığına tepkilerini ve kuraklığa hassasiyetlerinin değerlendirilerek, terminal gelișme dönemi kuraklığına toleranslı ekmeklik buğday genotiplerinin belirlenmesi amaçlanmıștır.

\section{Materyal ve Yöntem}

Bu araștırma, 2009-2010 yetișme dönemlerinde Bahri Dağdaș Uluslararası Tarımsal Araștırma Enstitüsü (BDUTE) arazisinde yürütülmüștür. Deneme yerinin 2009-2010 yetiștirme dönemlerine ait bazı iklim elemanlarının aylık ortalama değerleri Çizelge 1 'de verilmiștir. Bölgede uzun yıllar ortalaması yıllık toplam yağıș ortalaması 321.4 mm iken deneme yılında gerçekleșen yıllık toplam yağıș miktarı 385.4 mm olmuștur. Deneme yılına ait yağıș toplamı uzun yıllar ortalamasının (321.4 $\mathrm{mm}$ ) oldukça üzerinde gerçekleșmiștir. Ürün yılının sıcaklık ortalaması $\left(12.8^{\circ} \mathrm{C}\right)$ uzun yılların $\left(11.6^{\circ} \mathrm{C}\right)$ üzerinde gerçekleșmesi olum süresini hızlandırmıștır.

Deneme alanı topraklarının 0-30 cm ve 30$60 \mathrm{~cm}$ derinlik kademelerinden alınan toprak örnekleri üzerinde yapılan analize göre, tekstür sınıfının killi-tın, organik madde içeriğinin orta düzeyde (\%2.53 ve \%1.12), kireç içeriğinin yüksek (\%29.48 ve \%33.16), elverișli fosfor miktarının (11.06-6.99 kg/da) yeterli seviyede, potasyum bakımından (88.89-62.17 kg/da) zengin durumda ve alkali $(\mathrm{pH}: 8.30)$ reaksiyon gösterdiği belirlenmiștir.

Araștırmada bitkisel materyal olarak yedi adet tescilli çeșit (Karahan 99, Bayraktar 2000, Gerek 79, Dağdaș 94, Bezostaja 1, Göksu 99, Konya 2002) ile BDUTAE ekmeklik buğday ıslah programında kuru tarım alanları için geliștirilmiș iki adet ileri hat (BDME 09/1 K, BDME 09/2 K) ve bir adet yerel çeșit (0809 KEBVD 24) olmak üzere toplam on adet ekmeklik buğday genotipi kullanılmıștır.

Araștırma "tesadüf blokları deneme planında, bölünmüș parseller düzenlemesine" göre dört tekerrürlü olarak düzenlenmiștir. Denemede kuraklık ve takviye su uygulamaları ana parsellere, genotipler alt parsellere yerleștirilmiștir. $\mathrm{Bu}$ denemede parseller 0.8 $\mathrm{m} \times 1.5 \mathrm{~m}=1.2 \mathrm{~m}^{2}$ ebadında tertiplenmiș olup, her parselde dört sıra olacak șekilde 20 $\mathrm{cm}$ sıra arası ve $40 \mathrm{~cm}$ parsel arası mesafesi uygulanmıștır. Alt parseller içinde yer alan 10 genotip tekerrürlere șansa bağlı olarak dağıtılmıștır. Ana konu olarak ele alınan kuraklık ve takviye sulama uygulamaları așağıdaki șekilde uygulanmıștır.

Uygulamalar: Bitki gelișim dönemleri Zadoks Skalası (ZD) dikkate alınarak belirlenmiștir. 
Çizelge 1. Konya ilinde bazı iklim elemanlarının uzun yıllar ortalaması ve deneme yılına ait aylık ortalamaları Table 1. The average of long-term of some climate elements and the monthly average of the experiment year in Konya

\begin{tabular}{|c|c|c|c|c|c|c|c|c|c|c|c|c|c|c|}
\hline & AYLAR & Eylül & Ekim & Kasım & Aralık & Ocak & Șubat & Mart & Nisan & Mayıs & Haz. & Tem. & Ağus. & Yillık \\
\hline \multirow{5}{*}{$\begin{array}{l}{ }^{*} \\
0^{\circ} \\
> \\
\end{array}$} & Ort. Sı & 3.7 & 2.6 & 9 & 5 & .3 & 1. & 5.7 & .1 & 15.8 & 0.4 & 3.6 & 3.2 & 1.6 \\
\hline & Maks. Sıc. $\left({ }^{\circ} \mathrm{C}\right)$ & 36.1 & 31.6 & 25.2 & 20.0 & 17.6 & 21.2 & 28.9 & 31.5 & 33.4 & 37.2 & 40.6 & 37.8 & 40.6 \\
\hline & Min Sic. $\left({ }^{\circ} \mathrm{C}\right)$ & 1.2 & -7.6 & -20.0 & -22.4 & -25.8 & -25.0 & -15.8 & -8.6 & -1.2 & 3.2 & 7.5 & 7.5 & -25.8 \\
\hline & Yağıș (mm) & 11.6 & 32.2 & 37.6 & 41.9 & 34.4 & 24.4 & 26.2 & 38.8 & 41.7 & 20.1 & 7.5 & 0 & 321.4 \\
\hline & Nisbi $r$ & 46.0 & 58.0 & 69.0 & 77.0 & 76.0 & 70.0 & 62.0 & 58.0 & 55.0 & 47.0 & 42.0 & 42.0 & 58.5 \\
\hline \multirow{5}{*}{ 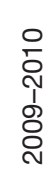 } & Ort. $\varsigma$ & 6.8 & 14.3 & 5.6 & 4.3 & 2.5 & 5. & 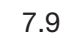 & 10.4 & 16.3 & 19.7 & 24.7 & 25.9 & 12.8 \\
\hline & Maks. Sic. $\left({ }^{\circ} \mathrm{C}\right)$ & 30.6 & 28.3 & 19.2 & 17.0 & 17.2 & 20.0 & 23.7 & 22.5 & 30.2 & 31.3 & 37.4 & 38.4 & 38.4 \\
\hline & Min. Sic. $\left({ }^{\circ} \mathrm{C}\right)$ & -0.4 & 2.0 & -6.0 & -7.2 & -12.0 & -9.2 & -7.5 & -1.7 & 2.1 & 6.7 & 9.2 & 13.2 & -12.0 \\
\hline & Yağıș & 2.2 & 14.4 & 60.6 & 72.4 & 43.4 & 33.0 & 14.6 & 27.6 & 13.6 & 76.2 & 7.4 & 0.0 & 385.4 \\
\hline & Nisbi nem (\%) & 51.8 & 54.7 & 82.6 & 87.9 & 85.2 & 74.1 & 60.8 & 64.7 & 50.0 & 57.4 & 40.6 & 32.0 & 61.8 \\
\hline
\end{tabular}

${ }^{*}$ Ort. Sıc.: Ortalama Sıcaklık, Maks. Sıc.: Maksimum Sıcaklık, Min. Sıc.: Minimum Sıcaklık

**U. Y. O.: 1975-2008 dönemine ait ortalama değerler (DMi)

${ }^{*}$ Avg. Temp.: Average Temperature, Max. Temp.: Maximum Temperature, Min. Temp.: Minimum Temperature

${ }^{*} A$. L. T.: The average values for the period 1975-2008 (SMW)

S: Tane dolum dönemi (ZD: 70-94) kuraklığı; bu parseller geç dönem kuraklığını test etmek amaciyla tane dolum döneminde kuraklığa maruz bırakılmıștır. $\mathrm{S}_{1}$ uygulama ana parselinde yer alan bitkiler sapa kalkma bașlangıcı dönemine (ZD: 30) kadar (Nisan ayına kadar) açıkta bırakılmıș, bu dönemden itibaren tane dolum dönemi sonuna kadar yağmur korunağı ile örtülerek, bitkilerin yağıș alması engellenmiștir. ZD: 30-50 döneminde $35 \mathrm{~mm}$ ve ZD: $50-70$ döneminde $50 \mathrm{~mm}$ olacak șekilde, uzun yıllar ortalaması seviyesinde damlama sulama ile su verilmiștir.

$\mathbf{S}_{2}$ : Tam sulu koșullar; bu parsellere buğday genotiplerinin verim potansiyellerinin belirlenmesi ve kuraklık uygulamalarındaki genotiplerin kuraklığa tepkilerinin belirlenmesinde kontrol olarak değerlendirilmesi amacıyla, ZD: 30-50 döneminde $50 \mathrm{~mm}$, ZD: 50-70 döneminde 80 $\mathrm{mm}$ ve ZD: $70-94$ döneminde $50 \mathrm{~mm}$ olacak șekilde damlama sulama uygulaması yapılmıștır. Ayrıca, yağmur korunağı altına alınmayarak yağıștan da yararlanması sağlanmıștır.

Tane dolum döneminde olușturulan yapay kuraklık uygulaması, polietilen parsel örtüsü $(0.25 \mathrm{~mm}$ kalınlıkta ve fotosentetik ıșığın \%95'ini geçirebilen) kullanılarak, sabit konumlu yağmur korunağı ile sağlanmıștır. Örtü kenarlarda toprak seviyesinden 1.5 $\mathrm{m}$ yükseklikte ve parsel kenarlarından $2 \mathrm{~m}$ etrafa tașacak șeklide yerleștirilmiștir (Öztürk, 1999a). Bütün parseller diğer uygulamaların etkilerinden korunmak için sulama ve örtülerin uygulanmadığı ilave parseller ile izole edilmiștir.
Ayrıca, yağmur korunağı kullanılan parsellerde, örtüden akan yağmur suları, açılan drenaj kanalları ile parsellerden uzaklaștırımıștır. Denemede ana parsellere sulama uygulamaları damlama sulama yöntemi ile yapılmıș olup, uygulanacak su miktarı her ana parselin bașinda yer alan sekonder su borusuna monte edilen hassas su saati ile ölçülerek verilmiștir.

Kuraklıkuygulamasında $\left(\mathrm{S}_{1}\right)$ ekimden yağmur korunağı örtülünceye kadar $266 \mathrm{~mm}$ yağıș alınırken, $S_{2}$ uygulamasında ise tane doldurma dönemi sonuna kadar alınan yağıș miktarı 347.8 $\mathrm{mm}$ olarak gerçekleșmiștir. Thermohygrograph cihazı ile yapılan ölçümlerde, örtülerin kuraklık uygulanan parsellerde havanın nispi nemi ve sıcaklığını değiștirmediği belirlenmiștir.

Deneme nadas-buğday münavebe sisteminde nadastan sonra kurulmuștur. Ekim ayının üçüncü haftasında deneme planına uygun olarak parselasyon yapılmıștır. Sıra arası $20 \mathrm{~cm}$ olacak șekilde, yaylı tırmık ile 5-6 $\mathrm{cm}$ derinlikte açılan çizilere $\mathrm{m}^{2}$ 'ye 550 adet tohum sıklığında elle ekilmiștir. Ana parseller $7 \mathrm{~kg} \mathrm{~N} \mathrm{da}^{-1}, 6 \mathrm{~kg} \mathrm{P}_{2} \mathrm{O}_{5}$ da $^{-1}$ olacak șekilde gübrelenmiștir. Fosforun tümü ve azotun 2.35 $\mathrm{kg} \mathrm{da}^{-1} \mathrm{kIsm}$, ekimden önce ana parsellere uygulanmıștır. Azotun geri kalan $4.65 \mathrm{~kg} \mathrm{da}^{-1}$ kısmı ise sapa kalkma dönemi bașlangıcında verilmiștir. Yabancı ot mücadelesi kimyasal ilaç uygulanarak ve zaman zaman elle koparılarak yapılmıștır. Parseldeki bitkiler hasat olgunluğuna geldiğinde orakla biçilerek parsel biçerdöveriyle harman edilmiștir. 
Araștırmada tane verimi (Kalaycı ve ark., 1998), bașaklanma süresi, çiçeklenme süresi, fizyolojik olum süresi ve tane dolum süresi (Zadoks et al., 1974) parametrelerine ilișkin gözlem ölçümler alınmıștır. Ayrıca, incelenen özelliklerde kuraklık hassasiyet indeksi (Fischer and Maurer, 1978) değerlendirmesi yapılmıștır.

Denemelerden elde edilen verilerin değerlendirilmesinde, varyans analizi yapılmıș ve farklııkları önemli olan özelliklerin ortalama değerleri LSD (\%5) testine göre gruplandırımıștır. Verilerin analizinde JMP 5.0.1 istatistik programı kullanılmıștır.

\section{Bulgular ve Tartıșma}

İncelenen özelliklerin tamamında kuraklık uygulaması etkili olmuș ve tüm özellikler bakımından uygulamalar, genotipler, uygulama $x$ genotip interaksiyonları arasındaki farklıık $(p<0.01)$ istatistiki olarak önemli bulunmuștur (Çizelge 2).

İncelenen özelliklere ait ortalama değerler ve önemlilik grupları Çizelge 3'te verilmiștir. Tane verimi genel ortalaması $669 \mathrm{~kg} \mathrm{da}^{-1}$ olarak belirlenmiș olup, bu değer bölge koșullarına göre nispeten yüksek olmuștur. Bunda, deneme yılında kuraklık uygulamasının bașlatılmasından (ZD: 30) önceki elverișli iklim koșulları etkili olmuștur. Nitekim, ZD: 30 dönemine kadar uzun yıllar ortalaması yağıș miktarı $196 \mathrm{~mm}$ iken, deneme yılında $266 \mathrm{~mm}$ ile \%35 daha fazla gerçekleșmiștir (Çizelge 1).
Tam sulu koșullar $\left(\mathrm{S}_{2}\right)$ uygulamasından ortalama $760 \mathrm{~kg} \mathrm{da}^{-1}$ tane verimi elde edilirken, tane dolum dönemi kuraklık uygulamasında $\left(\mathrm{S}_{1}\right)$ ortalama tane verimi $579 \mathrm{~kg} \mathrm{da}^{-1}$ olmuștur. Kontrol uygulaması ile karșılaștırıldığında $\mathrm{S}_{1}$ uygulamasında kuraklığa tepki olarak \%23.9 verim kaybı belirlenmiștir. Farklı gelișme dönemlerindeki kuraklığın tane verimi üzerindeki etkisine ilișkin yapılan araștırmalarda (Jamal et al., 1996; Kimurto et al., 2003; Öztürk, 1999b) çalıșmamızdakine benzer sonuçlar rapor edilmiștir.

Ekmeklik buğday genotiplerinden ortalama en yüksek tane verimi $725 \mathrm{~kg} \mathrm{da}^{-1}$ ile BDME 09/1K genotipinden elde edilirken, Konya 2002, Karahan 99, 08-09 KEBVD 24 ve BDME 09/2K genotipleri sırasıyla 719, 709, 706 ve 691 $\mathrm{kg} \mathrm{da}^{-1}$ verim değerleri ile genel ortalamanın üzerinde bir performans göstermiștir. Göksu 99 çeșidi ise en düșük tane verimine $(595 \mathrm{~kg}$ $\mathrm{da}^{-1}$ ) sahip olmuștur. Uygulamalar ile genotipler arasındaki interaksiyonlar incelendiğinde, $\mathrm{S}_{1}$ uygulamasının genotiplerin verimi üzerine önemlivaryasyonlarolușturduğugörülmektedir. Genotiplerin $S_{1}$ uygulamasındaki kuraklığa gösterdikleri tepkilere bakıldığında, Bayraktar 2000 en az verim kaybı gösterirken, Bezostaja 1, Dağdaș 94, Gerek 79, BDME 09/2K, BDME 09/1K ve 08-09 KEBVD 24 genotipleri ortalama verim kaybından daha az verim kaybı göstermișlerdir. $S_{1}$ uygulamasındaki genotipler KHI ile değerlendirildiğinde, Göksu 99 ve Karahan 99 dıșındaki genotiplerin tane verimi

Çizelge 2. Tane doldurma döneminde kuraklık uygulanan 10 ekmeklik buğday genotipine uygulanan varyans analizine ait kareler ortalamaları

Table 2. Mean squares of variance analysis applied to 10 wheat genotypes applied drought during grain filling period

\begin{tabular}{|c|c|c|c|c|c|c|}
\hline Varyasyon Kaynakları & SD* & TV & BS & ÇS & FS & TDS \\
\hline Tekerrür & 3 & 5872.21 & 0.217 & 1.746 & 0.546 & 1.167 \\
\hline Kuraklık & 1 & $658833^{\star *}$ & $217.8^{\star \star}$ & $308.13^{\star *}$ & $1665.31^{* *}$ & $551.25^{\star \star}$ \\
\hline Hata 1 & 3 & 2993.24 & 0.3 & 0.079 & 0.313 & 1.15 \\
\hline Genotipler & 9 & $17664^{\star \star}$ & $46.13^{\star \star}$ & $42.196^{\star \star}$ & $41.318^{\star \star}$ & $5.689^{\star \star}$ \\
\hline Kuraklık*Genotipler & 9 & $8132.93^{\star \star}$ & $1.217^{\star \star}$ & 0.863 & $1.063^{* *}$ & $2.75^{\star \star}$ \\
\hline Hata 2 & 54 & 2804.4 & 0.3787 & 0.551 & 0.198 & 0.445 \\
\hline Genel & 79 & & & & & \\
\hline VK (\%) & & 7.9 & 0.36 & 0.42 & 0.20 & 1.78 \\
\hline
\end{tabular}

*SD: Serbestlik derecesi, VK: Varyasyon katsayısı, TV: Tane verimi, BS: Bașaklanma süresi, ÇS: Çiçeklenme süresi, FS: Fizyolojik olum süresi, TDS: Tane dolum süresi, ${ }^{*}{ }^{*}(p<0.01)$

${ }^{\star} D F$ : Degree of freedom, VC: Variation coefficient, GY: Grain yield, HP: Heading period, FP: Flowering period, DPM: Duration of physiological maturity, GFP: Grain filling period, ${ }^{* *}(p<0.01)$ 
Çizelge 3. Tane doldurma döneminde kuraklık uygulanan 10 adet ekmeklik buğday genotipine ait tane verimi ve bazı fenolojik özelliklerin ortalama değerleri

Table 3. Mean values of grain yield and some phenological properties of 10 bread wheat genotypes subjected to drought during grain filling period

\begin{tabular}{|c|c|c|c|c|c|c|c|c|c|}
\hline \multirow{2}{*}{ Genotip } & \multicolumn{3}{|c|}{ Tane Verimi $\left(\mathrm{kg} \mathrm{da}^{-1}\right)$} & \multicolumn{3}{|c|}{ Bașaklanma Süresi (gün) } & \multicolumn{3}{|c|}{ Çiçeklenme Süresi (gün) } \\
\hline & $\mathrm{S}_{1}^{*}$ & $\mathrm{~S}_{2}$ & GO & $\mathrm{S}_{1}$ & $\mathrm{~S}_{2}$ & GO & $\mathrm{S}_{1}$ & $\mathrm{~S}_{2}$ & $\mathrm{GO}$ \\
\hline Karahan 99 & $577 \mathrm{gh}^{\star \star}$ & $841 \mathrm{a}$ & $709 a b$ & $168.0 \mathrm{f}$ & $171.5 \mathrm{~d}$ & $169.8 \mathrm{~d}$ & $173.5 \mathrm{ij}$ & $177.3 \mathrm{~d}$ & $175.4 \mathrm{~cd}$ \\
\hline Bayraktar 2000 & $586 \mathrm{gh}$ & 679 def & $633 \mathrm{~cd}$ & I65.0 I & $168.0 \mathrm{f}$ & $166.5 \mathrm{~h}$ & $171.0 \mathrm{I}$ & $175.0 \mathrm{fg}$ & $173.0 \mathrm{f}$ \\
\hline Gerek 79 & $587 \mathrm{gh}$ & $751 \mathrm{bcd}$ & $669 \mathrm{bc}$ & $168.0 \mathrm{f}$ & $171.0 \mathrm{~d}$ & $169.5 \mathrm{de}$ & 173.8 hı & $178.0 \mathrm{bcd}$ & $175.9 \mathrm{c}$ \\
\hline Dağdaș 94 & $554 \mathrm{~h}$ & 703 cde & $629 \mathrm{~cd}$ & $172.8 \mathrm{c}$ & $175.5 \mathrm{a}$ & $174.1 \mathrm{a}$ & $177.8 \mathrm{~cd}$ & $181.5 \mathrm{a}$ & $179.6 \mathrm{a}$ \\
\hline Bezostaya 1 & $563 \mathrm{gh}$ & 680 def & $622 \mathrm{~cd}$ & $169.8 \mathrm{e}$ & $173.5 \mathrm{bc}$ & $171.6 \mathrm{c}$ & $174.8 \mathrm{gh}$ & 178.8 bc & $176.8 \mathrm{~b}$ \\
\hline Göksu 99 & 441 । & $749 \mathrm{bcd}$ & $595 d$ & $172.8 \mathrm{c}$ & $174.3 \mathrm{~b}$ & $173.5 \mathrm{~b}$ & $178.8 \mathrm{bc}$ & $181.3 \mathrm{a}$ & $180.0 \mathrm{a}$ \\
\hline Konya 2002 & $622 \mathrm{fgh}$ & $816 a b$ & $719 a b$ & $166.8 \mathrm{gh}$ & $171.0 \mathrm{~d}$ & $168.9 f$ & $172.5 \mathrm{jk}$ & $177.5 \mathrm{~d}$ & $175.0 \mathrm{~d}$ \\
\hline BDME 09/1K & 635 efg & $815 a b$ & $726 \mathrm{a}$ & $166.3 \mathrm{~h}$ & $170.0 \mathrm{e}$ & $168.1 \mathrm{~g}$ & $171.5 \mathrm{kl}$ & 176.0 ef & $173.8 \mathrm{e}$ \\
\hline BDME 09/2K & $605 \mathrm{fgh}$ & $776 \mathrm{abc}$ & $691 \mathrm{ab}$ & $167.3 \mathrm{fg}$ & $171.0 \mathrm{~d}$ & 169.1 ef & 173.0 ij & $177.0 \mathrm{de}$ & $175.0 \mathrm{~d}$ \\
\hline 08-09 KEBVD 24 & $618 \mathrm{fgh}$ & $795 a b$ & $706 a b$ & $169.8 \mathrm{e}$ & $173.5 \mathrm{bc}$ & $171.6 \mathrm{c}$ & $175.5 \mathrm{fg}$ & $179.0 \mathrm{~b}$ & $177.3 \mathrm{~b}$ \\
\hline Stres Uyg. Ort. & $579 \mathrm{~b}$ & $760 \mathrm{a}$ & 669 & $168.6 \mathrm{~b}$ & $171.9 \mathrm{a}$ & 170.3 & 174.2 & 178.1 & 176.2 \\
\hline \multirow{2}{*}{ Genotip } & \multicolumn{3}{|c|}{ Fizyolojik Olum Süresi (gün) } & \multicolumn{3}{|c|}{ Tane Doldurma Süresi (gün) } & & & \\
\hline & $\mathrm{S}_{1}$ & $\mathrm{~S}_{2}$ & GO & $\mathrm{S}_{1}$ & $\mathrm{~S}_{2}$ & GO & & & \\
\hline Karahan 99 & $208.5 \mathrm{kl}$ & $218.3 \mathrm{de}$ & $213.4 d$ & 35.00 def & $40.50 \mathrm{ab}$ & $37.75 \mathrm{a}$ & & & \\
\hline Bayraktar 2000 & $205.5 n$ & $213.3 \mathrm{~h}$ & $209.4 \mathrm{~g}$ & 34.50 efg & $38.25 \mathrm{c}$ & $36.38 \mathrm{bc}$ & & & \\
\hline Gerek 79 & 208.01 & $216.0 \mathrm{~g}$ & $212.0 \mathrm{f}$ & $34.25 \mathrm{fg}$ & $38.00 \mathrm{c}$ & $36.13 \mathrm{c}$ & & & \\
\hline Dağdaș 94 & $213.0 \mathrm{~h}$ & $222.0 \mathrm{a}$ & $217.5 \mathrm{a}$ & $35.25 \mathrm{de}$ & $40.50 \mathrm{ab}$ & $37.88 \mathrm{a}$ & & & \\
\hline Bezostaya 1 & 209.3 j & $218.8 \mathrm{~cd}$ & $214.0 \mathrm{c}$ & 34.50 efg & $41.00 \mathrm{a}$ & $37.75 \mathrm{a}$ & & & \\
\hline Göksu 99 & 211.5 I & $221.0 \mathrm{~b}$ & $216.3 b$ & $32.75 \mathrm{~h}$ & $39.75 \mathrm{~b}$ & $36.25 \mathrm{c}$ & & & \\
\hline Konya 2002 & $208.3 \mathrm{kl}$ & $217.3 f$ & $212.8 \mathrm{e}$ & $35.75 d$ & $39.75 b$ & $37.75 \mathrm{a}$ & & & \\
\hline BDME 09/1K & $207.3 \mathrm{~m}$ & $216.8 f$ & $212.0 \mathrm{f}$ & $35.75 \mathrm{~d}$ & $40.75 \mathrm{a}$ & $38.25 \mathrm{a}$ & & & \\
\hline BDME 09/2K & $208.8 \mathrm{jk}$ & $218.0 \mathrm{e}$ & $213.4 d$ & $35.75 \mathrm{~d}$ & $41.00 \mathrm{a}$ & $38.38 \mathrm{a}$ & & & \\
\hline 08-09 KEBVD 24 & $209.3 \mathrm{j}$ & $219.3 \mathrm{c}$ & $214.3 \mathrm{c}$ & $33.75 \mathrm{~g}$ & $40.25 \mathrm{ab}$ & $37.00 \mathrm{~b}$ & & & \\
\hline Stres Uyg. Ort. & 208.9 b & $218.1 \mathrm{a}$ & 213.5 & $34.7 \mathrm{~b}$ & $39.8 \mathrm{a}$ & 37.25 & & & \\
\hline
\end{tabular}

${ }^{*} \mathrm{~S}_{1}$ : Tane dolum dönemi kuraklık uygulaması, $\mathrm{S}_{2}$ : Tam sulu koșullar, GO: Genotip ortalamaları

${ }^{* *}$ Aynı harflerle gösterilen değerler arasında istatistiki açıdan farklılık yoktur $(P<0.05)$.

${ }^{*} S_{1}$ : Grain filling period drought aplication, $S_{2}$ : Full water conditions, GA: Genotype averages,

** There is no statistically significant difference between the values indicated by the same letters $(P<0.05)$

bakımından TD kuraklı̆ına toleranslı oldukları belirlenmiștir (Çizelge 4). Konya 2002 çeșidi ise genel olarak orta düzeyde bir kuraklık toleransı sergilemiștir. $S_{2}$ uygulamasında genotipler arasında verim $841 \mathrm{~kg} \mathrm{da}^{-1}$ (Karahan 99) ile $679 \mathrm{~kg} \mathrm{da}^{-1}$ (Bayraktar 2000) arasında değișim göstermiștir. $S_{1}$ uygulamasında toleransı bulunan Konya 2002, BDME 09/1K, 08-09 KEBVD 24 ve BDME 09/2K genotipleri $S_{2}$ uygulamasında da bașarılı genotipler olarak ön plana çıkmıștır. Bu yüzden, bu genotiplerin TD dönemi kuraklığı bakımından diğer genotiplere göre daha stabil oldukları söylenebilir.

Bașaklanma süresi $S_{2}$ uygulamasında ortalama 171.9 gün olarak gerçekleșirken, $S_{1}$ uygulamasında \%1.9 performans kaybı ile 168.6 gün olmuștur. Genotiplerde bașaklanma süresi 166.5 gün (Bayraktar 2000) ile 175.5 gün
(Dağdaș 94) arasında değișmiștir. Genotiplerin $\mathrm{S}_{1}$ uygulamasındaki kuraklığa gösterdikleri tepkiler değerlendirildiğinde, Göksu 99 en az bașaklanma süresi kaybı (1.5 gün) gösterirken, Konya 2002 en yüksek tepki (4.2 gün) veren çeșit olmuștur. Nitekim, sulu ve kuru koșullarda yürütülen çalıșmalarda, kuraklık stresinin sulu koșullara göre, bașaklanma süresinde 1-8 gün arasında değișen bir kısalmaya neden olduğu rapor edilmiștir (Kalaycı, 1998; Öztürk, 1999a; Cseuz et al., 2008). Bașaklanma süresinde Dağdaș 94, Gerek 79 ve Bayraktar 2000 çeșitleri ortalama performans kaybından (3.3 gün) daha az kayıp göstermișlerdir (Çizelge 3). $\mathrm{S}_{1}$ uygulamasındaki genotipler $\mathrm{KHI}$ ile değerlendirildiğinde, Bayraktar 2000, Gerek 79, Dağdaș 94, Göksu 99 ve Karahan 99 çeșitlerinin BS bakımından TD kuraklı̆ına toleranslı oldukları belirlenmiștir (Çizelge 4). 
Çizelge 4. Tane doldurma döneminde kuraklık uygulanan 10 adet ekmeklik buğday genotipine ait tane verimi ve bazı fenolojik özelliklere ilișkin kuraklık hassasiyet indeksleri

Table 4. Drought sensitivity indexes of grain yield and some phenological properties of 10 bread wheat genotypes subjected to drought during grain filling period

\begin{tabular}{lccccc}
\hline \multirow{2}{*}{ Genotipler } & \multicolumn{5}{c}{ Kuraklık Hassasiyet İndeksleri } \\
\cline { 2 - 6 } & TV $^{*}$ & BS & ÇS & FS & TDS \\
\hline Karahan 99 & 1.32 & 1.06 & 0.98 & 1.06 & 1.04 \\
Bayraktar 2000 & 0.58 & 0.93 & 1.04 & 0.87 & 0.75 \\
Gerek 79 & 0.92 & 0.91 & 1.08 & 0.88 & 0.76 \\
Dağdaș 94 & 0.89 & 0.80 & 0.93 & 0.96 & 0.99 \\
Bezostaya 1 & 0.72 & 1.11 & 1.02 & 1.03 & 1.22 \\
Göksu 99 & 1.73 & 0.45 & 0.63 & 1.02 & 1.35 \\
Konya 2002 & 1.00 & 1.28 & 1.29 & 0.98 & 0.77 \\
BDME 09/1K & 0.93 & 1.13 & 1.17 & 1.04 & 0.94 \\
BDME 09/2K & 0.93 & 1.13 & 1.03 & 1.00 & 0.98 \\
08-09 KEBVD 24 & 0.93 & 1.11 & 0.89 & 1.08 & 1.24 \\
Kuraklık Șiddeti (\%) & 23.9 & 1.9 & 2.2 & 4.2 & 13.0 \\
\hline${ }^{*}$ TV: Tane verimi, BS: Bașaklanma süresi, ÇS: Çiçeklenme süresi, FS: Fizyolojik olum süresi, TDS: Tane dolum süresi \\
${ }^{*}$ GY: Grain yield, HP: Heading period, FP: Flowering period, DPM: Duration of physiological maturity, GFP: Grain filling period
\end{tabular}

Çiçeklenme süresi $\mathrm{S}_{2}$ uygulamasında 178.1 gün, $\mathrm{S}_{1}$ uygulamasında ise kuraklı̆ın etkisiyle $\% 2.1$ oranında kısalarak 174.2 gün olarak gerçekleșmiștir. Genotiplerde çiçeklenme süresi 173 gün (Bayraktar 2000) ile 180 gün (Göksu 99) arasında değișmiștir. $S_{1}$ uygulamasında çiçeklenme süresi kısalma tepkisi en az Göksu 99 (2.5 gün) çeșidinde görülürken, en yüksek tepki beș gün ile Konya 2002 çeșidinde belirlenmiștir. Nitekim, Frederick and Bauer (1999) bașaklanma tarihi, tane büyüme hızı, fizyolojik olgunlașma süresi ve tane doldurma süresinin bașaklanmadan sonraki çevre koșulları tarafından kontrol edildiğini belirtmișlerdir. 08-09 KEBVD 24, Dağdaș 94 ve Karahan 99 genotipleri $S_{1}$ uygulamasında ortalama çiçeklenme süresi kısalmasından daha az performans kaybı göstermișlerdir.

$\mathrm{S}_{1}$ uygulamasındaki genotipler $\mathrm{KHI}$ ile değerlendirildiğinde, Bayraktar 2000, Gerek 79, Dağdaș 94, Göksu 99 ve Karahan 99 çeșitlerinin ÇS bakımından TD kuraklı̆ı̆ına toleranslı oldukları belirlenmiștir (Çizelge 4).

Fizyolojik olum süresinin geç dönem kuraklığından BS ve ÇS parametrelerine göre daha fazla etkilendiği belirlenmiștir. FS $S_{2}$ uygulamasında 218.1 gün, $S_{1}$ uygulamasında ise \%4.2 kısalma ile 208.9 gün olmuștur. Genotiplerde FS 209.4 gün (Bayraktar 2000) ile 217.5 gün (Dağdaș 94) arasında değișmiștir. $S_{1}$ uygulamasında FS süresi kısalması bakımından en düșük tepki 7.8 gün ile Bayraktar 2000 çeșidinde görülürken, 08-09 KEBVD 24 genotipi 10 günlük kısalma ile en yüksek tepkiyi vermiștir. $\mathrm{S}_{1}$ uygulamasındaki genotipler $\mathrm{KHI}$ ile değerlendirildiğinde, Bayraktar 2000, Gerek 79, Dağdaș 94 ve Konya 2002 çeșitlerinin FS bakımından TD kuraklığına daha toleranslı oldukları belirlenmiștir (Çizelge 4).

Geç dönem kuraklığı fenolojik özellikler içinde oransal olarak en fazla tane dolum süresi üzerinde etkili olmuștur. TDS $S_{2}$ uygulamasında 39.9 gün, $S_{1}$ uygulamasında ise $\% 13.0$ kısalma ile 34.7 gün olarak gerçekleșmiștir. TDS genotiplerde 36.13 gün (Gerek 79 ) ile 38.38 gün (BDME 09/2K) arasında değișim göstermiștir. $\mathrm{S}_{1}$ uygulamasında TDS kısalması bakımından en düșük tepki Bayraktar 2000 çeșidinden (4.25 gün) alınırken, en yüksek tepki Göksu 99 çeșidinden (7 gün) elde edilmiștir. Frederick and Bauer (1999), tane doldurma süresinde verim bașaklanmadan sonraki koșullar tarafından belirlendiği için, bu dönemde tanede endosperm hücreleri ve burada olușan nișasta granüllerinin büyüklüğü, tanenin elde edilebilir asimilatlardan yararlanma kapasitesinin de etkili olduğunu belirtmișlerdir. $\mathrm{S}_{1}$ uygulamasındaki genotipler KHi ile değerlendirildiğinde, Bayraktar 2000, Gerek 79, Konya 2002, Dağdaș 94, BDME 09/1K ve BDME 09/2K genotiplerinin TDS bakımından TD kuraklığına daha toleranslı oldukları belirlenmiștir (Çizelge 4). 


\section{Sonuç}

2009-2010yetiștirmedönemlerindekontrollü koșullarda, ekmeklik buğday genotiplerinin TD dönemi kuraklığına tepkileri araștııımıș; genotiplerin verim ve fenolojik dönemlerindeki tolerans düzeyini belirlemek için stres uygulamasındaki performans kayıpları ve $\mathrm{KHI}$ kullanılmıștır. Geç dönem kuraklı̆ı̆ıa, fizyolojik olum süresinin $\mathrm{BS}$ ve ÇS parametrelerine göre daha fazla tepki gösterdiği belirlenmiștir. Buna bağlı olarak, genotiplerin tane dolum sürelerinde önemli varyasyon olduğu görülmüș; TD süresi bakımından toleranslı olan ve TD süresi uzun olan genotiplerin verim değerlerinin de yüksek olduğu belirlenmiștir. Bu sonuçlara göre, geç dönem kuraklığı görülen bölgelere adaptasyonu yüksek çeșitlerin geliștirilmesi hedeflenen ıslah programlarında TD süresi önemli bir seleksiyon parametresi olarak kullanılabilir.
Ayrıca, incelenen tüm parametreler yönüyle TD dönemi kuraklığına Bayraktar 2000, Gerek 79 ve Dağdaș 94 çeșitleri toleranslı bulunurken, TD süresi parametresi bakımından bu çeșitlere Konya 2002, BDME 09/1K ve BDME 09/2K genotipleri de dahil olmuștur. Bu genotipler araștırmaya konu olan hedef bölgelerde yetiștirilebileceği önerilirken, aynı zamanda yeni geliștirilecek buğday çeșitleri için ıslah programlarında önemli bir gen kaynağı olarak da değerlendirilebilir.

\section{Teșekkür}

Bu çalıșmayı 1090822 nolu proje ile 1002 Hızlı Destek Programı kapsamında destekleyen TÜBITAK'a ve projenin yürütülmesinde her türlü imkanı sağlayan BDUTAE'ne katkılarından dolayı müteșekkiriz.

\section{Kaynaklar}

Aliyev J.A., and Huseynova I.M., 2014. Genotypic Variation for Drought Tolerance in Wheat Plants. (Improvement of Crops in The Era of Climatic Changes, Ed. P. Ahmad et al.) Volume 2: 151-169. doi: 10.1007/978-1-46148824-8_6

Czeuz L., Pauk J., Fonad P., Kovacs E., and Matuz J., 2008. Field selection of winter wheat genotypes tolerant to water shortage with a mobile automatic rain shelter (MARS) and chemical desiccation. Cereal Research NonProfit Co., Szeged, Hungary, p: 1-3

Fischer R.A., and Maurer R., 1978. Drought resistance in spring wheat cultivars. I. Grain yield response. Australian Journal of Agricultural Research, 29: 897-912. doi: 10.1071/ AR9780897

Frederick J.R., and Bauer P.J., 1999. Physiological and Numerical Components of Wheat Yield. In: Satorre, E.H., Slafer, G.A. (Ed.). Wheat: Ecology and Physiology of Yield Determination, USA: CRC Press.) p. 54

Gupta N.K., Gupta S., and Kumar A., 2001. Effect of water stress on physiological attributes and their relationship with growth and yield of wheat cultivars at different stages. Journal of Agronomy \& Crop Science, 186: 55-62

Jamal M, Nazir M.S., Shah S.H., and Ahmed N., 1996. Varietal response of wheat to water stress at different growth stages. III. Effect on grain yield, straw yield, harvest index and protein content in grain. Rachis, 15 (1/2): 38-45

Kınacı E. ve Dayığlu R., 1998. Determination of Drought Resistant Wheat Genotypes and Related Morphological and Physiological Parameters Under Central Anatolian Conditions, TÜBITAK Projesi Sonuç Raporu, 62

Kimurto P.K., Kinyua M.G., and Njoroge J.M., 2003. Response of bread wheat genotypes to drought simulation under a mobile rain shelter in Kenya. African Crop Science Journal, 11: 225-234

Öztürk A., 1999a. Ekmeklik buğday genotiplerinde kurağa dayanıklılık. Turkish Journal of Agriculture and Forestry, 23 ek sayı:5: 1237-1247

Öztürk A., 1999b. Kuraklığın kıșlık buğdayın gelișmesi ve verimine etkisi. Turkish Journal of Agriculture and Forestry, 23: 531-540

Sade B., 2008. Yeni boyutlarıyla kuraklık ve nadas. Ülkesel Tahıl Sempozyumu, 2-5 Haziran, Konya, Türkiye, s. 230-235

Saidi A., Ookawa T., Motobayashi T., and Hirasawa T., 2008. Effects of soil moisture conditions before heading on growth of wheat plants under drought conditions in the ripening stage: insufficient soil moisture conditions before heading render wheat plants more resistant to drought to ripening. Plant Production Science, 11: 403-411. doi: 10.1626/pps.11.403

Schnyder H., 1993. The role of carbohydrate storage and redistribution in the source-sink relations of wheat and barley during grain filling-a review. New Phytologist Journal., 123: 233-245

Zadoks J.C., Chang T.T., and Konzak C.F., 1974. A decimal code for the growth stages of cereals. Weed Research, Volume 14: 415-421 